\title{
Erratum: Divergent activity of the
} gonadotropin-releasing hormone receptor gene promoter among genetic lines of pigs is partially conferred by nuclear factor (NF)$\mathrm{kB}$, specificity protein (SP)1-like and GATA-4 binding sites

Emily A. McDonald ${ }^{1,2+}$, Jacqueline E. Smith ${ }^{1,3+}$, Rebecca A. Cederberg ${ }^{1}$ and Brett R. White ${ }^{1 *}$

\section{Update and Erratum}

The title for the original version of this article [1] unfortunately contained an error. '(NF)-B' has been corrected to '(NF)-kB'.

\section{Author details}

'Laboratory of Reproductive Biology, Department of Animal Science, Institute of Agriculture and Natural Resources, University of Nebraska-Lincoln, Lincoln, NE, USA. ${ }^{2}$ Present address: Center for International Health Research, Rhode Island Hospital, Providence, RI, USA. ${ }^{3}$ Present address: Stowers Institute for Medical Research, Kansas City, MO, USA.

Received: 30 June 2016 Accepted: 1 July 2016

Published online: 25 July 2016

\section{Reference}

1. McDonald et al. Reproductive Biology and Endocrinology (2016) 14:36. doi: 10.1186/s12958-016-0170-0

*Correspondence: bwhite2@unl.edu

'Equal contributors

${ }^{1}$ Laboratory of Reproductive Biology, Department of Animal Science, Institute of Agriculture and Natural Resources, University of Nebraska-Lincoln, Lincoln, $N E$, USA

Full list of author information is available at the end of the article

\footnotetext{
Submit your next manuscript to BioMed Central and we will help you at every step:

- We accept pre-submission inquiries

- Our selector tool helps you to find the most relevant journal

- We provide round the clock customer support

- Convenient online submission

- Thorough peer review

- Inclusion in PubMed and all major indexing services

- Maximum visibility for your research
}

Submit your manuscript at www.biomedcentral.com/submit 